\title{
Opinions of International Students on Choosing a State University in a Developing Country
}

\author{
Adnan Boyaci ${ }^{\mathrm{a} \otimes}$ and Yakup $\mathrm{Oz}^{\mathrm{b} \bowtie}$
}

\begin{abstract}
In this study, factors affecting the college choice of international students (CCIS) are investigated based on the opinions of international students at a state university (Anadolu University) in Turkey. A case study design is employed and opinions of students are analyzed in accordance with whether they are scholarship or non-scholarship students. In the findings, three main themes emerge; intent to study abroad, choosing to study in Turkey, and choosing to study at Anadolu University. These themes cover several factors affecting the CCIS. In this regard, there are no critical differences between the factors affecting the opinions of scholarship and non-scholarship students. However, some factors could differentiate in accordance with the background characteristics of the students and whether they are from high-income or non-highincome countries.
\end{abstract}

\section{Introduction}

The college choice of international students (CCIS) has become a popular research field in higher education since international student mobility has become a movement in recent decades. If the number of international students is estimated at 8 million (Altbach, 2004), and they are all taken as at least undergraduate students and then the overall expenses (tuition fees, accommodation, education books/equipment, food and etc.) for undergraduate education are estimated as approximately 71,000 U.S. dollars (Hongkong and Shanghai Banking Corporation [HSBC], 2017), the total market value of international higher education can be calculated to be around 568 billion dollars by 2025. In this regard, CCIS can be regarded as an essential part of student mobility in the international higher education market (Hemsley-Brown \& Oplatka, 2016). Therefore, an examination of factors associated with how international students choose colleges is crucial.

\footnotetext{
a Department of Educational Science, Anadolu University.

${ }^{b}$ Department of Educational Science, Karamanoglu Mehmetbey University.

${ }^{凶}$ Corresponding authors: adnanboyaci2100@gmail.com (Adnan Boyaci), yakupoz573@yahoo.com (Yakup Oz)
} 
The aim of this study is to investigate factors leading international students to choose to study in a developing country. In this regard, this research is a case study focusing on the factors affecting the process of international students choosing to study in a state university in Turkey. According to the international students' report of the Ministry of Development (2015), international students are defined as "foreign national students in the Turkish Republic, having student visas or special permits to study at any level of education and training, with or without a scholarship" (p. 18). The same definition is also used in this study. Most literature on CCIS focuses mostly on developed, high-income countries like the US, the UK, and Australia (Bodycott, 2009; Chen, 2007; Maringe, \& Carter, 2007; Mazzarol, \& Soutar 2002; McCarthy, Sen, \& Fox Garrity, 2012; Pimpa, 2003), which are among the top destinations for international students, with a high number of topranked colleges. This study contributes to understanding international students' choices of colleges in developing and upper middle-income countries.

\section{Literature Review}

\section{Theories on CCIS}

Theories related to the CCIS are a combination of college choice theories for domestic students and migration theories. Considering the college choice of domestic students, sociological models come first. These models focus on how students' social and psychological structures influence the choice of higher education institutions (Hossler, Schmit, \& Vesper, 1999; McDonough, 1997; Plank, \& Jordan, 2001). These models investigate the effect of socioeconomic status, family conditions, school environment, individual characteristics, and school adjustment on college choice (Hossler et al., 1999; Paulsen, 1990). However, students are not just affected by surrounding factors; they investigate the costs and benefits of going to college as rational actors, proposed by economic models (Kotler \& Fox, 1985). Before they attend a college, they analyze their job preferences, potential earnings or benefits of post-graduation, fees, accommodation, and separation from family and friends (Hossler et al., 1999; McDonough, 1997). In this way, the college choice process follows certain steps, such as need arousal, information search, evolution of alternatives, decision implementation, and post-purchase evolution (Kotler \& Fox, 1985). These two different perspectives on college choice are gathered together in combined models assuming that the choice of the college is an incremental process rather than a single decision (Hossler et al., 1999). This process consists of three stages: predisposition, search, and choice. Predisposition is the tendency of a student to go to college or not. In the search stage, there is interaction between the student and institutions as students seek information about the colleges. In the third stage, students choose a specific college by evaluating their choice set that they prepared, based on the information from the second stage (Hossler \& Gallaghar, 1987).

With CCIS, migration theories come to the forefront (Lee, 1966). Push and pull factors for a country play an essential role in students' decisions as to whether or not to go abroad for higher education. The prestige of the foreign colleges, career opportunities after graduation, and opportunities offered by the host country to international students are among the pulling factors, while different obstacles, such as low quality of education 
and political or economic turmoil in the country are examples of the pushing factors (Altbach, 2004; Mazzarol \& Soutar 2002; McMahon, 1992). Mazzaroul and Soutar (2002) examined the process of college choice in three stages: deciding to study internationally or nationally, selection of the host country, and selection of the institution. Pushing and pulling factors are more related to the second stage, considering the economic and political forces in the home country, and various attractive forces in the host country.

However, CCIS cannot be devoted only to the pushing and pulling factors, considering the outgoing students from developed, high-income countries, not experiencing any political or economic turmoil, or having a good quality higher education. Sociological and economic models still need to be taken into consideration. Chen (2007) proposed a model that is a synthesis of the combined models including the three-phase model of Hossler and Gallaghar (1987) and (Neice \& Braun, 1977), and push and pull factors (Mazzarol, \& Soutar, 2002). This synthesis model is more likely based on econometric and marketing models with a closer look at sociological models and social capital theory. The model elaborates the choice process into three stages: deciding to study abroad, choosing the host country, and choosing the institution. In each stage, student characteristics, significant others, and external push-pull factors affect students' decisions (Chen, 2007, s. 760).

\section{Internationalization of Higher Education in a Turkish Context}

Turkey has a history of internationalization of higher education from the late Ottoman period. Modernization efforts and the negative results of wars made Ottoman officials renew the army and, for the first time, they established military schools. In these schools, there were foreign commanders responsible for the training of students. During World War II, a number of scholars who had escaped from Germany joined the government institutions and the academic staff of universities (Kirisci, 2000; Reisman, 2007). Since 1827, during the rule of Sultan Mahmud II, selected students have been provided with a government scholarship to take higher education abroad (Aslan, 2014), which is also an ongoing tradition in the modern Turkish Republic.

Despite such a long history of outgoing student and incoming faculty mobility, an intensive internationalization movement started only later. A new basis for internationalization emerged in the 1990s and 2000s with the Bologna Process, consisting of the European Credit Transfer System (ECTS), the diploma supplement, the Erasmus agreements. However, steps to attract international students are still relatively new for Turkey. These steps can be specified in the following three items:

1. The Grand Student Project:This project was started in 1992 for students in states established after the dissolution of the Soviet Union. However, it then spread to 57 states or communities. Within the project, between 1992-2008, 27,112 students received scholarships (Ministry of National Education [MoNE], 2009).

2. The Mevlana Exchange Program:Turkey established its own international student exchange program named Mevlana in 2011. This program covers bilateral agreements with higher institutions throughout the world, except for European Union member countries, since Turkey is already a part of the Erasmus Program. 
3. Türkiye Scholarships:Turkey recently established this scholarship program for international students and faculty members under the supervision of the Precedency for Turks Abroad and Related Communities. This program has operated since 2010, with 16,000 students being provided with scholarships in 105 universities (Türkiye Scholarships).

In Turkey, there has been no significant fluctuation in the total number of international students since the beginning of the Grand Student Project up to 2008. However, the number of incoming international students has started to increase in recent years. There were approximately 48,000 international students in 2013 , with $80 \%$ of these studying at state universities, and $60 \%$ living in metropolitan cities like Istanbul, Ankara, and Izmir (Ministry of Development, 2015). According to the Higher Education Information Management System (HEIMS) data, the total number of international students, including exchanges, was 108,076 in 2017 (HEIMS).

Such an increase in the number of international students in the last 5 years is mainly the result of two important factors. The first is the political support for internationalization, because the internationalization for Turkish higher education is considered as soft power in international politics (Kaya, 2014). Unlike hard power, soft power implies that other actors change their behaviors in line with the power-holder preferences, not by making a cost-benefit calculation or by being forced to do so, but they view the power-holder's actions or demands are legitimate. In this regard, civilian means of power are more preferable rather than military aspects of power (Oğuzlu, 2007). Hence educational, cultural or economic ties among countries are more valuable resources for creating soft power and affecting each other in the international arena. According to the president of the Council of Higher Education (CoHE), such an increase in the number of international students in the last 5 years is the result of planned action, and for the next 5 years the aim is to reach 200,000 international students without exchanges, as declared in the 2018-2022 Internationalization Strategy Document (Saraç, 2017). The second is Turkey's natural capacity for internationalization. According to Kondakci (2010), Turkey has a distinct process in the internationalization of higher education for four main reasons. First, Turkey's geopolitical position is a natural bridge between East and West, and this position makes for easier access to developed industrial countries for international students. Second, Turkey has an Anglo-Saxon higher education system, which enables degree equivalencies, meeting EU standards and international cooperation between higher education institutions. Third, Turkey has historical and cultural bonds between the Balkans, North Africa, the Middle East, Caucasia, and Central Asia, providing an important position in the region. Last is the macroeconomic capacity of Turkey that provides engagement with western economies. International students have a chance to find job opportunities both in Turkey and western countries by studying in such an economically, academic, politically, and geographically engaged country.

\section{Anadolu Universityand the International Students}

Anadolu University was established in 1958. It has two campuses including 17 faculties (colleges/schools/departments at undergraduate level), with three of these offering 
distance education. These three faculties consisted of almost three million students in the 2016-2017 educational year (HEIMS), which makes Anadolu University one of the largest universities by enrollment in the world.

Anadolu University is also effective in bilateral agreements and exchange programs. The Office for International Affairs was founded to carry out the internationalization process of Anadolu University in 2003. The Office for International Affairs provides service on Erasmus and Mevlana student exchange programs, European Voluntary Service, dual degree programs, and international co-operation protocols with other higher education institutions. There have been 55 protocols, 508 agreements, 3,269 outgoing and 1,224 incoming students, and 1,279 outgoing and 374 incoming members of staff leading up to 2016.

Between 2013 and 2017, there was a 130\% increase in the total number of international students, with a total of 4,778 international students in 2017 (HEIMS). Anadolu University is also listed among the top ranked 1,000 universities by the Times Higher Education World Rankings in 2018, and it is the 17th university in Turkey according to the same scale (Anadolu University).

\section{Research Method}

In this research, the embedded single-case study design was applied, considering the target case consists of two groups of international students: international students with scholarships and those without. A case study is "a detailed examination of one setting, or one single subject, or one single depository of documents or one particular event" (Bogdan\&Biklen, 1992, p. 62), within its real-life context and in which multiple sources of evidence exist (Fraenkel \&Wallen, 2008).

Regarding multiple sources of evidence about the process of CCIS, we only used semistructured interviews, mainly because we conducted the research after students were already admitted to Anadolu University. So, we couldn't have a chance to benefit from various data collecting techniques like observations or participant diaries. This is one of the limitations of this study. However, a case study also requires the analysis of a bounded system (Creswell, 2014; Merriam, 2009), which is in this case, the academic and social environment of Anadolu University. Moreover, the last stage of the hierarchical college choice process is the selection of the college, figuring out the discussion related to theories on the CCIS. In this regard, this research is automatically limited to the context of the Anadolu University, and the results are naturally constrained by the unique characteristics of it. Hence, when this qualitative research was designed as a case study, the uniqueness of Anadolu University as a bounded system was on the forefront, despite the limitation of a single data-collecting technique.

\section{Participants}

There are 21 participants in the study. Fifteen of these are scholarship and six are nonscholarship international students. Table 1 reresents the characteristics of the participants. All names are coded as $\mathrm{P} 1, \mathrm{P} 2, \ldots \mathrm{P} 21$, where $\mathrm{P}$ is for the participant. 
Table 1. Characteristics of the Participants

\begin{tabular}{|c|c|c|c|c|c|}
\hline & $\begin{array}{l}\text { Country/ } \\
\text { Geographic } \\
\text { location }\end{array}$ & $\begin{array}{l}\text { Income } \\
\text { type }\end{array}$ & $\begin{array}{l}\text { Student } \\
\text { type }\end{array}$ & Departments & $\begin{array}{l}\text { Class } \\
\text { Gender }\end{array}$ \\
\hline $\mathrm{P} 1$ & $\begin{array}{l}\text { Turkmenistan } \\
\text { Central Asia }\end{array}$ & $\begin{array}{l}\text { Upper- } \\
\text { middle }\end{array}$ & NS & Architecture & $\begin{array}{l}\text { Senior } \\
\text { Male }\end{array}$ \\
\hline P2 & $\begin{array}{l}\text { Kyrgyzstan } \\
\text { Central Asia }\end{array}$ & $\begin{array}{l}\text { Lower- } \\
\text { middle }\end{array}$ & $S$ & Economics & $\begin{array}{l}\text { Senior } \\
\text { Male }\end{array}$ \\
\hline P3 & $\begin{array}{l}\text { Azerbaijan } \\
\text { Western Asia }\end{array}$ & $\begin{array}{l}\text { Upper- } \\
\text { middle }\end{array}$ & NS & $\begin{array}{l}\text { Computer Education \& } \\
\text { Instructional Technology }\end{array}$ & $\begin{array}{l}\text { Soph. } \\
\text { Male }\end{array}$ \\
\hline $\mathrm{P} 4$ & $\begin{array}{l}\text { Mauritania } \\
\text { Western Africa }\end{array}$ & $\begin{array}{l}\text { Lower- } \\
\text { middle }\end{array}$ & $S$ & Journalism & $\begin{array}{l}\text { Senior } \\
\text { Male }\end{array}$ \\
\hline P5 & $\begin{array}{l}\text { Colombia } \\
\text { South America }\end{array}$ & $\begin{array}{l}\text { Upper- } \\
\text { middle }\end{array}$ & S & Architecture & $\begin{array}{l}\text { Junior } \\
\text { Female }\end{array}$ \\
\hline P6 & $\begin{array}{l}\text { France } \\
\text { Western Europe }\end{array}$ & High & NS & $\begin{array}{l}\text { English Language Teach- } \\
\text { ing }\end{array}$ & $\begin{array}{l}\text { Junior } \\
\text { Female }\end{array}$ \\
\hline P7 & $\begin{array}{l}\text { Afghanistan } \\
\text { Southern Asia }\end{array}$ & Low & NS & $\begin{array}{l}\text { English Language Teach- } \\
\text { ing }\end{array}$ & $\begin{array}{l}\text { Junior } \\
\text { Female }\end{array}$ \\
\hline P8 & $\begin{array}{l}\text { Iraq } \\
\text { Western Asia }\end{array}$ & $\begin{array}{l}\text { Upper- } \\
\text { middle }\end{array}$ & S & Cinema and Television & $\begin{array}{l}\text { Soph. } \\
\text { Male }\end{array}$ \\
\hline P9 & $\begin{array}{l}\text { Indonesia } \\
\text { Southeastern Asia }\end{array}$ & $\begin{array}{l}\text { Lower- } \\
\text { middle }\end{array}$ & $S$ & Business Administration & Freshma \\
\hline P10 & $\begin{array}{l}\text { Turkmenistan } \\
\text { Central Asia }\end{array}$ & $\begin{array}{l}\text { Upper- } \\
\text { middle }\end{array}$ & NS & History & $\begin{array}{l}\text { Female } \\
\text { Senior } \\
\text { Male }\end{array}$ \\
\hline P11 & $\begin{array}{l}\text { Yemen } \\
\text { Western Asia }\end{array}$ & Low & $S$ & Sociology & $\begin{array}{l}\text { Junior } \\
\text { Male }\end{array}$ \\
\hline P12 & $\begin{array}{l}\text { Afghanistan } \\
\text { Southern Asia }\end{array}$ & Low & $S$ & $\begin{array}{l}\text { Environmental Engineer- } \\
\text { ing }\end{array}$ & $\begin{array}{l}\text { Soph. } \\
\text { Male }\end{array}$ \\
\hline P13 & $\begin{array}{l}\text { Sudan } \\
\text { Northern Africa }\end{array}$ & $\begin{array}{l}\text { Lower- } \\
\text { middle }\end{array}$ & NS & $\begin{array}{l}\text { Electrical \& Electronics } \\
\text { Engineering }\end{array}$ & $\begin{array}{l}\text { Senior } \\
\text { Male }\end{array}$ \\
\hline P14 & $\begin{array}{l}\text { Ukraine } \\
\text { Eastern Europe }\end{array}$ & $\begin{array}{l}\text { Lower- } \\
\text { middle }\end{array}$ & $S$ & Journalism & $\begin{array}{l}\text { Junior } \\
\text { Female }\end{array}$ \\
\hline P15 & $\begin{array}{l}\text { Kazakhstan } \\
\text { Central Asia }\end{array}$ & $\begin{array}{l}\text { Upper- } \\
\text { middle }\end{array}$ & $S$ & Cinema \& Television & $\begin{array}{l}\text { Junior } \\
\text { Female }\end{array}$ \\
\hline P16 & $\begin{array}{l}\text { Somali } \\
\text { Eastern Africa }\end{array}$ & Low & S & Sociology & $\begin{array}{l}\text { Senior } \\
\text { Male }\end{array}$ \\
\hline P17 & $\begin{array}{l}\text { Myanmar } \\
\text { Southeastern Asia }\end{array}$ & $\begin{array}{l}\text { Lower- } \\
\text { middle }\end{array}$ & S & Chemistry & $\begin{array}{l}\text { Junior } \\
\text { Female }\end{array}$ \\
\hline P18 & $\begin{array}{l}\text { Chad } \\
\text { Middle Africa }\end{array}$ & Low & $S$ & Chemical Engineering & $\begin{array}{l}\text { Junior } \\
\text { Male }\end{array}$ \\
\hline
\end{tabular}




\begin{tabular}{llllll}
\hline \multicolumn{5}{c}{ Table 1 continued } \\
\hline & $\begin{array}{c}\text { Country/ } \\
\text { Geographic } \\
\text { location }\end{array}$ & $\begin{array}{c}\text { Income } \\
\text { type }\end{array}$ & $\begin{array}{c}\text { Student } \\
\text { type }\end{array}$ & Departments & $\begin{array}{l}\text { Class } \\
\text { Gender }\end{array}$ \\
\hline P19 & $\begin{array}{l}\text { Afghanistan } \\
\text { Southern Asia }\end{array}$ & Low & S & Architecture & $\begin{array}{l}\text { Junior } \\
\text { Male }\end{array}$ \\
P20 & $\begin{array}{l}\text { Thailand } \\
\text { Southeastern Asia }\end{array}$ & $\begin{array}{l}\text { Upper } \\
\text { middle }\end{array}$ & S & Economics & Freshman \\
& Lower- & S & Journalism & Male \\
P21 & $\begin{array}{l}\text { Uzbekistan } \\
\text { Central Asia }\end{array}$ & $\begin{array}{l}\text { Lenior } \\
\text { middle }\end{array}$ & & & Female \\
\hline
\end{tabular}

S = Scholarship, NS = Non-scholarship;

Most of the participants are from low or lower middle-income economies of Africa and Asia, and just one of them is from a European high-income country. These definitions for geographic location and the income type of the countries were made in accordance with the M49 Standard prepared by the Statistics Division of the United Nations (UN) Secretariat (M49 Standard) and the World Bank (WB) Atlas method (World Bank Country and Lending Groups) respectively. In this regard, Turkey is located in the Western Asia and an upper middle-income economy.

In 2017, most of the international students at Anadolu University are male (3159), with a few (945) coming from high-income countries (HEIMS). Hence, the study group can be considered as consisting of an appropriate composition of the total 4,778 international students as a case study, when the characteristics of participants (13 male and one high income country) are examined from Table 1.

A specific criterion and snowball sampling methods were used to determine the participants. The criterion was that each participant must have passed the Turkish Language Proficiency Exam. Students in the Turkish Language Preparatory Classes were not included in the research, in order to conduct interviews in Turkish. In addition, each participant had to have had experience in their departments, even if they were in their first semester. If students are still in the Turkish Language Preparatory Classes, they cannot select any departmental course.

We contacted participants through their friends and members of International Students' Club (ISC). After interviewing one participant, we were able to find another participant based on information received from the initial interviewee. However, in order to overcome certain limitations of the snowball sampling regarding diversity, we tried to contact participants from different countries and departments by the help of ISC, since the club is an important focal point for international students.

\section{Data Collection}

In the research, data was collected through semi-structured interviews and was tape recorded by the researchers. Semi-structured interviews are very useful to control the course of the interviews while maintaining freedom of speech of the interviewees 
(Creswell, 2003) and to reduce any prejudices of the researchers (McMillan \& Schumacher, 1993, p. 426).

Apart from questions relating to demographics, the interview form consisted of three main questions regarding the decision-making processes to study abroad, to study in Turkey, and to study at Anadolu University for higher education. For the initial interview form, interview questions were prepared in accordance with the literature, and the suggestions of two faculty members in the field of educational administration. Next, four international students were interviewed as a pilot study. After the pilot study, interview questions were re-examined with suggestions from the same field experts, and the final semi-structured questionnaire form was created.

Prior to the interviews, a consent form showing the voluntary participation of the international students involved and the responsibility of the researchers to keep the voice recordings and student information confidential was signed by the researchers and the participants. All the interviews took 30 minutes to conduct on average.

Two researchers participated in all of the interviews. They took individual notes on the explanations of the participants. The interviews were conducted in the researchers' room, a library and at the ISC. Before each interview, researchers stated the goal of the study, gave time to participants for getting familiar with the interview questions and explained how important is their plain expressions in order to eliminate biases originated by participant expectations.

During the course of interviews, researchers avoided unnecessary comments and stuck with the interview questions to eliminate the researcher bias. Before the study, researchers thought that the main reason for scholarship students to study in Turkey is simply the scholarships they have. But as the number of interviews has increased, researchers noticed that there are other factors for scholarship students as important as having a scholarship, and most of these factors were also shared by non-scholarship students.

\section{Transcription of Interviews, Coding, and Analysis of the Data}

After the interviews, the researchers took an exact transcription of the voice recordings. Both the transcriptions and the notes of the researchers were used to create the codes, categories, and themes. The thematic analysis method is employed for the analysis.

Thematic analysis was chosen because of its flexibility (Braun \& Clarke, 2006) and qualitative nature (Vaismoradi, Turunen \& Bondas, 2013). First of all, a deductive approach was used to create categories and themes during the analysis, guided by the literature, and mostly by Chen's (2007) synthesis model. According to Clarke and Braun (2014), thematic analysis can be used deductively when the analysis is driven by pre-existing theories and frameworks. Thematic analysis can also be used for an analysis of the data gathered by the different range of questions, focusing on the perspectives, practices, influencing factors, and construction of specific social processes (Clarke \& Braun 2014). In this research, we mainly focused on influencing factors related to the CCIS. Furthermore, during the analysis, a low level of interpretation was preferred compared to grounded theory or hermeneutic phenomenology, but still both the latent and the manifest content were considered (Vaismoradi, Turunen \& Bondas, 2013). 
The analysis conducted by the researchers together, followed a path advised by Braun and Clarke (2006). In this regard, after becoming familiar with the data, researchers reached the subthemes and themes based on the codes and the literature. Then they sought advice from the same field experts when reviewing and defining the themes. In the end, the last form of the themes was created. All the voice records, notes, and transcriptions used in the analysis are kept confidential.

Regarding validity and reliability, all processes in the methodology part, pilot study, refinement of the interview form (based on the results of the pilot study), and expert opinions are good for reliability or internal validity; a criterion sampling method and detailed results are also good for the external validity of the study. In addition, creating the themes in the order of codes-categories-subthemes-themes in accordance with the goal of the study, research questions, expert opinions and the literature, and keeping all documents related to research for the audit trail, makes the analysis is more reliable (Merriam, 1998).

\section{Findings}

According to the aim of the study, the opinions of the participants can be categorized into three main themes; intent to go abroad, choosing to study in Turkey, choosing to study at Anadolu University. Table 2 shows the basic factors constituting the themes by the participant type (Scholarship Participant - SP or Non-Scholarship Participant - N-SP), the role of the factor (Pushing or Pulling) and the country type (High-Income Country - HIC or Non-High-Income Country - N-HIC).

\section{Intent to Go Abroad}

There are four main subthemes: academic and economic motives, significant others and individual characteristics, which have inspired the participants to go abroad for higher education. These subthemes do not differ between the scholarship and the nonscholarships students. As an example of academic factors, both the scholarship and non-scholarship students emphasized, "the prestige of a foreign diploma" and "their motivation to achieve better educational opportunities". In addition, "the contribution of a foreign degree when applying for a job in their home country" was again the shared economic factor to go abroad by both groups of students.

Sisters, brothers, families, friends, and alumni all influencing an intention to go abroad, are the categories of significant others for both scholarship and non-scholarship students. However, "family support for abroad education, advice, and encouragements of friends, talks with alumni of universities located in Turkey, and sisters/brothers taking the same scholarship (Türkiye Scholarships)" are mostly mentioned by the scholarship students. Furthermore, one non-scholarship student emphasized a kind of tradition or a norm indicating the general status of students who have high expectations and educational aspirations for abroad education at his high school (P3): 
Table 2. Basic Factors Constituting the Themes

\begin{tabular}{|c|c|c|c|c|c|c|}
\hline Basic factors & $\mathrm{SP}$ & $\mathrm{N}-\mathrm{SP}$ & Pushing & Pulling & HIC & N-HIC \\
\hline \multicolumn{7}{|l|}{ Intend to go abroad } \\
\hline Prestige of a foreign diploma & P2, P15 & P1, P7 & & $\mathrm{X}$ & & $\mathrm{X}$ \\
\hline Reaching better educational opportunities & $\begin{array}{l}\text { P8, P11, P12, } \\
\text { P17, P20 }\end{array}$ & P10 & & $\mathrm{X}$ & & $\mathrm{X}$ \\
\hline $\begin{array}{l}\text { Contribution of a foreign degree during the } \\
\text { job application }\end{array}$ & P14, P19 & $\mathrm{P} 1$ & & $\mathrm{X}$ & & $\mathrm{X}$ \\
\hline Family support for abroad education & $\begin{array}{l}\text { P2, P5, P11, P13, } \\
\text { P15, P17, P18, } \\
\text { P21 }\end{array}$ & $\mathrm{P} 7$ & $\mathrm{X}$ & & & $\mathrm{X}$ \\
\hline Advice and encouragements of friends & P16, P19 & & $\mathrm{X}$ & & & $\mathrm{X}$ \\
\hline Talks with alumni of universities abroad & & P3 & $\mathrm{X}$ & & & $\mathrm{X}$ \\
\hline Sisters/brothers taking Türkiye Scholarships & P5 & P7 & & $\mathrm{X}$ & & $\mathrm{X}$ \\
\hline Learning a foreign language & $\begin{array}{l}\mathrm{P} 2, \mathrm{P} 5, \mathrm{P} 12, \mathrm{P} 13 \\
\mathrm{P} 14, \mathrm{P} 15, \mathrm{P} 17\end{array}$ & $\mathrm{P} 10$ & $\mathrm{X}$ & & & $\mathrm{X}$ \\
\hline Personal development & $\begin{array}{l}\text { P4, P5, P8, P9, } \\
\text { P11, P12, P14, } \\
\text { P15, P16, P17, } \\
\text { P18, P19, P20, } \\
\text { P21 }\end{array}$ & P1, P3, P6, P10 & $\mathrm{X}$ & & $\mathrm{X}$ & $\mathrm{X}$ \\
\hline Personal/Professional interests & $\begin{array}{l}\mathrm{P} 4, \mathrm{P} 8, \mathrm{P} 11, \mathrm{P} 12, \\
\mathrm{P} 19\end{array}$ & $\mathrm{P} 10$ & $\mathrm{X}$ & & & $\mathrm{X}$ \\
\hline Desire to go abroad & P9 & & $\mathrm{X}$ & & & $\mathrm{X}$ \\
\hline \multicolumn{7}{|l|}{ Choosing to study in Turkey } \\
\hline $\begin{array}{l}\text { Turkey has good quality of education and } \\
\text { great number of universities }\end{array}$ & $\begin{array}{l}\text { P2, P4, P9, P11, } \\
\text { P12, P13, P17, } \\
\text { P18, P19 }\end{array}$ & P1, P3, P7, P10 & & $\mathrm{X}$ & & $\mathrm{X}$ \\
\hline
\end{tabular}




\begin{tabular}{|c|c|c|c|c|c|c|}
\hline \multicolumn{7}{|l|}{ Table 2 continued } \\
\hline Basic factors & SP & N-SP & Pushing & Pulling & HIC & N-HIC \\
\hline $\begin{array}{l}\text { Bilateral agreements of Turkish universities } \\
\text { with European counterparts }\end{array}$ & P18 & P3 & & $\mathrm{X}$ & & $\mathrm{X}$ \\
\hline $\begin{array}{l}\text { Inadequacies in the higher education system } \\
\text { and institutions in the home country }\end{array}$ & P11 & P3 & $\mathrm{X}$ & & & $\mathrm{X}$ \\
\hline Low quality of education in the home country & $\begin{array}{l}\text { P4, P11, P16, } \\
\text { P17, P18, P19 }\end{array}$ & P7, P10 & $\mathrm{X}$ & & & $\mathrm{X}$ \\
\hline $\begin{array}{l}\text { More job opportunities in home country after } \\
\text { graduation from Turkey }\end{array}$ & $\begin{array}{l}\text { P2, P5, P12, P13, } \\
\text { P16, P17, P18 }\end{array}$ & P3, P7, P10 & & $\mathrm{X}$ & & $\mathrm{X}$ \\
\hline Türkiye Scholarships & $\begin{array}{l}\text { P4, P5, P8, P9, } \\
\text { P11, P12, P14, } \\
\text { P20 }\end{array}$ & & & $\mathrm{X}$ & & $\mathrm{X}$ \\
\hline Low cost of education in Turkey & P20 & $\mathrm{P} 6$ & & $\mathrm{X}$ & $\mathrm{X}$ & $\mathrm{X}$ \\
\hline High cost of education in home country & P5, P16 & P6 & $\mathrm{X}$ & & $\mathrm{X}$ & $\mathrm{X}$ \\
\hline Integration of western values & $\begin{array}{l}\text { P2, P8, P11, P14, } \\
\text { P16, P18, P20 }\end{array}$ & P3, P6 & & $\mathrm{X}$ & $\mathrm{X}$ & $\mathrm{X}$ \\
\hline Intolerance of women's education & & P7 & $\mathrm{X}$ & & & $\mathrm{X}$ \\
\hline Cultural closeness & $\begin{array}{l}\text { P2, P4, P11, P12, } \\
\text { P15, P16, P17, } \\
\text { P18, P19, P20, } \\
\text { P21 }\end{array}$ & $\mathrm{P} 1, \mathrm{P} 3, \mathrm{P} 7$ & & $\mathrm{X}$ & & $\mathrm{X}$ \\
\hline Multicultural environment & $\begin{array}{l}\text { P2, P5, P8, P11, } \\
\text { P12, P14, P15, } \\
\text { P16, P18, P19 }\end{array}$ & P1, P3 & & $\mathrm{X}$ & & $\mathrm{X}$ \\
\hline Turkish TV shows & P2, P15, P21 & P10 & & $\mathrm{X}$ & & $\mathrm{X}$ \\
\hline Being familiar with the Turkish language & P2, P12 & P1, P3, P10 & & & & $\mathrm{X}$ \\
\hline Turkey as a secure country & P5, & P6, P7 & & $\mathrm{X}$ & & $\mathrm{X}$ \\
\hline
\end{tabular}




\begin{tabular}{|c|c|c|c|c|c|c|}
\hline Basic factors & SP & $\mathrm{N}-\mathrm{SP}$ & Pushing & Pulling & HIC & N-HIC \\
\hline $\begin{array}{l}\text { Special interstate agreements between } \\
\text { Turkey and the home country }\end{array}$ & P16 & & $\mathrm{X}$ & $\mathrm{X}$ & & $\mathrm{X}$ \\
\hline Home country support to study abroad & P18, P19 & & $\mathrm{X}$ & & & $\mathrm{X}$ \\
\hline $\begin{array}{l}\text { Ongoing wars and conflict areas in home } \\
\text { country }\end{array}$ & P8, P11, P14 & P7 & $\mathrm{X}$ & & & $\mathrm{X}$ \\
\hline $\begin{array}{l}\text { The low level of democracy in the home } \\
\text { country }\end{array}$ & P11, P18, P20 & & $\mathrm{X}$ & & & $\mathrm{X}$ \\
\hline $\begin{array}{l}\text { Bribery in the public administration and the } \\
\text { education system }\end{array}$ & P21 & P3, P10 & $\mathrm{X}$ & & & $\mathrm{X}$ \\
\hline Turkey is near to the home country & P11 & P3 & & $\mathrm{X}$ & & $\mathrm{X}$ \\
\hline Turkey is near to European countries & P2 & P3 & & $\mathrm{X}$ & & $\mathrm{X}$ \\
\hline Family members living or studying in Turkey & $\mathrm{P} 4, \mathrm{P} 17$ & & & $\mathrm{X}$ & & $\mathrm{X}$ \\
\hline Friends in Turkey & $\begin{array}{l}\text { P8, P12, P13, } \\
\text { P16 }\end{array}$ & $\mathrm{P} 1, \mathrm{P} 10$ & & $\mathrm{X}$ & & $\mathrm{X}$ \\
\hline $\begin{array}{l}\text { Siblings who are already a Türkiye Scholar- } \\
\text { ship student }\end{array}$ & & $\mathrm{P} 7$ & & $\mathrm{X}$ & & $\mathrm{X}$ \\
\hline Previous experiences in Turkey & & P6 & & $\mathrm{X}$ & $\mathrm{X}$ & \\
\hline Choosing to study at Anadolu University & & & & & & \\
\hline Popularity of Anadolu University & $\begin{array}{l}\mathrm{P} 2, \mathrm{P} 4, \mathrm{P} 5, \mathrm{P} 9 \\
\mathrm{P} 11, \mathrm{P} 12, \mathrm{P} 16, \\
\mathrm{P} 20\end{array}$ & P1, P3, P6, P7 & & $\mathrm{X}$ & $\mathrm{X}$ & $\mathrm{X}$ \\
\hline $\begin{array}{l}\text { The recognition of degrees and diplomas of } \\
\text { Anadolu University in home country and } \\
\text { Europe }\end{array}$ & P2, P20 & P6, P10 & & $\mathrm{X}$ & & $\mathrm{X}$ \\
\hline Presence of programs in English & P13 & P6 & & $\mathrm{X}$ & & $\mathrm{X}$ \\
\hline $\begin{array}{l}\text { Presence of top-ranked programs that the } \\
\text { participants want to study }\end{array}$ & $\begin{array}{l}\text { P8, P11, P12, } \\
\text { P15 }\end{array}$ & P3 & & $\mathrm{X}$ & & $\mathrm{X}$ \\
\hline
\end{tabular}




\begin{tabular}{|c|c|c|c|c|c|c|}
\hline Table 2 continued & & & & & & \\
\hline Basic factors & SP & $\mathrm{N}-\mathrm{SP}$ & Pushing & Pulling & HIC & N-HIC \\
\hline Siblings in the Anadolu University & & $\mathrm{P} 7$ & & $\mathrm{X}$ & & $\mathrm{X}$ \\
\hline $\begin{array}{l}\text { Teachers suggesting to study in the Anadolu } \\
\text { University }\end{array}$ & P2 & & $\mathrm{X}$ & & & $\mathrm{X}$ \\
\hline Friends in the Anadolu University & P20 & P3, P6, P10 & & $\mathrm{X}$ & $\mathrm{X}$ & $\mathrm{X}$ \\
\hline City is a 'student city' & $\begin{array}{l}\text { P4, P11, P13, } \\
\text { P15, P18 }\end{array}$ & P1, P3, P7, P10 & & $\mathrm{X}$ & & $\mathrm{X}$ \\
\hline Favorable living expenses in the city & $\mathrm{P} 2$ & P7 & & $\mathrm{X}$ & & $\mathrm{X}$ \\
\hline City is not crowded/populated & P18, P21 & $\mathrm{P} 1, \mathrm{P} 10$ & & $\mathrm{X}$ & & $\mathrm{X}$ \\
\hline City is a safe place to study & P18 & P10 & & $\mathrm{X}$ & & $\mathrm{X}$ \\
\hline
\end{tabular}


I graduated from a quality high school. In my country, students who enrolled in similar high schools, want to take higher education abroad. We regularly talked about studying abroad for higher education and taking advice from alumni. Other students stay in the country and go to national universities.

Considering individual characteristics, participants mentioned their personal interests in going abroad for higher education and their belief that higher education abroad would make a significant contribution to their personal development. However, the opinions of the scholarship students are more dominant in the construction of both categories. "Having the chance to learn a foreign language by going abroad" is a general example of the personal development category. Similarly, most of the students thought, higher education abroad is an adventure which would make them more independent in life and support them by establishing relationships with people from different cultures, ethnicities, and backgrounds. Hence, "higher education abroad would make a great contribution to their personal development" (P20). Apart from this, certain participants reveal that their personal and professional interests require higher education abroad. P4 from the Journalism Department mentioned, "his interest in the literature, history and politics of the Middle East and North Africa (MENA), and his desire to visit and see Andalusia and Anatolia, which also leads him to go abroad". However, for another (P9), higher education abroad is just an instrument to go abroad:

Going abroad has always been a dream for me. This desire increased in high school. Frankly, I had a scholarship for a university in my home country. In addition, this university is ranked higher than Anadolu University, but I wanted to have different experiences. This would make me different from my friends because I would experience things that my friends would never be able to.

\section{Choosing to Study in Turkey}

The opinions of the participants can be grouped into seven subthemes; academic, economic, cultural, political, geographic factors, significant others for both scholarship and non-scholarship students and background characteristics for only non-scholarship students. Moreover, some of these subthemes play a dual role in pushing students away from their home countries and drawing them to study in Turkey.

Academic factors are the most emphasized subtheme by both types of students. For most of the students, "Turkey has better quality education and a great number of universities, and accessing educational material is very easy in Turkey as it has bilateral agreements with European universities". P18 said that:

Turkey is not like Chad. We can do everything we want in Turkey. We can use the laboratories and make projects. Turkey has got a high level of education. I have gone to a university in Spain with the Erasmus program. It is at a higher level than Anadolu University in international rankings. However, when you look at the buildings, it looks like a house 
containing a different department on each floor. The laboratories are inadequate when compared with the labs at Anadolu University. So, I think that Turkey has a better education.

In this regard, academic factors play a dual role in pulling students to study in Turkey and pushing them away from their home countries. "Inadequacies in the higher education system and institutions and low quality of education in the home countries"also leads students of the MENA, central Asian and African countries to study in Turkey.

Economic factors are another subtheme of being pulled towards Turkey for both types of students. Some believe that "they can easily find jobs after graduating from an institution in Turkey because there are a number of Turkish corporations or Turkish schools that they can apply to a job in their home country". Apart from this, for scholarship students, Türkiye Scholarships is another factor all by itself, since it covers tuitions, accommodation, and monthly allowances till the end of education. In this context, they emphasize that "although they gained other scholarships from different countries, they still chose Turkey because of the broad extent of coverage of Türkiye Scholarships".

Furthermore, a great many students mention that "the cost of education by means of academic and non-academic expenses in Turkey is lower than in their home countries". The two students from Ukraine and France particularly emphasize that "the cost of education is very expensive in their countries, and most of the scholarships do not cover accommodation and other non-academic expenses. Besides, students have to take student loans out if they want to attend a four-year university course". Actually, this subtheme also plays a dual role for both scholarship and non-scholarship students. On the one hand, the low cost of education in Turkey attracts students to study in Turkey. On the other hand, though, the high cost of education in their home country pushes them away to study abroad.

Furthermore, all the cultural factors are shared by both types of students. These are the integration of western values, cultural closeness, multicultural environment, and Turkish TV shows. Most of the participants think that Turkey is between Europe and the Middle East/Asia in terms of the integration of western values just like its geographic location. Hence, for some participants (P3, P14) from post-Soviet countries, "The effect of old Soviet traditions in politics or governments is still going on, but Turkey is more familiar and integrated with western values". In addition, "Turkey is more democratic and modern than their countries" for some participants (P11, P18) coming from MENA countries. In a similar manner, a participant from France mentioned that (P6) "There is a similar perception of democracy in France and Turkey. There is laicism in Turkey. I wanted to study in a country where my freedom wouldn't be restricted. Turkey is such a place".

In that manner, a female, non-scholarship student (P7) complained about the intolerance of women's education in Afghanistan. According to her, "This situation is less favorable nowadays, but the idea is still effective". Hence, the intolerance of women's education is critical in pushing the student away from her home country.

Cultural closeness is mentioned by both types of students again, but the opinions of scholarship students are more dominant. Most of the students coming from MENA and central Asian countries deal with the "similar words of the language, similar religious 
practices, similar eating habits, and a shared history", which make them and their families feel close to Turkey and Turkish people. For example, P11 said that:

Turkey is a very beautiful country in the Middle East. It stands with you. Our mothers, fathers, and grandfathers love Turkey. We have got a connection, closeness. As an example, I had a friend who gained a scholarship from Germany, but he didn't go there. He chose Turkey. Why? It was because he loves Turkey.

Some students also emphasize the multicultural environment in Turkey. Most of them know that there are "many students from different countries coming to study in Turkey with the help of Türkiye Scholarships". After coming to Turkey, most of the scholarship and non-scholarship students have to take a preparatory Turkish language class and successfully complete it before beginning to take departmental courses. Hence, they have a chance to meet new people from different countries in these preparatory classes.

One of the original findings in the study is the effect of Turkish TV shows on the creation of the Turkey image in the minds of participants. Four participants (P2, P10, P15, P21), from both types of students, mention that:

After watching Turkish TV shows they started to wonder about Turkey and researched it. Besides, these TV shows make them feel close to Turkey. There is even the effect of Turkish TV shows on their families supporting students to study in Turkey.

Political factors are also mentioned by both scholarship and non-scholarship students. The opinions of the participants are mostly concentrated on "the status of Turkey as a secure country (P11, P14, P19), special interstate agreements between Turkey and the home country (P16), and home country support to study abroad" (P18). These were all effective on their decision to study in Turkey.

However, political factors also play a dual role which leads students to go abroad for higher education. Students from Ukraine and Yemen underlined that "the ongoing wars and conflict areas in their home countries lead the country into political turmoil and an unstable political condition. So, they need to go abroad for higher education". Similarly, one student (P20), emphasized, "the low level of democracy in his home country, since the government of the state is occupied by soldiers, which makes him unwilling to support the current leaders". Furthermore, two students (P3, P21) from a central Asia country, complained about the bribery in bureaucracy, reducing the trust in public administration and the education system. P21 told that "Even when you take the university entrance exam, you can bribe".

Again, both types of student explained the geographic factors leading them to study in Turkey. They emphasized the geographic proximity of Turkey and their home countries, and that of Turkey and Europe, by underlining that, "Turkey is very near to their home countries and it is a door, a bridge to Europe".

Significant others emerge as another subtheme for being drawn towards Turkey. For both types of students, "family members, friends in Turkey" are the major agents 
encouraging and suggesting studying in Turkey. For the scholarship students especially, "siblings who have already achieved Türkiye Scholarships and who are still studying in Turkey”, recommend studying in Turkey.

Apart from this, there is another subtheme, which is background characteristics, only mentioned by a non-scholarship student from France talking about her experiences in Turkey. "She came to Turkey a few times for summer holidays". Actually, during the pilot interviews, a similar factor was emphasized by a non-scholarship student from Germany. That student was a one-year Erasmus exchange student in Turkey (Anadolu University) during her undergraduate education. Hence, for a student from a high-income western European country, previous individual experience of Turkey could be effective on their choice to study in Turkey in later years.

\section{Choosing to Study at Anadolu University}

The opinions of the participants can be grouped into three subthemes; academic factors, significant others and city characteristics. These are the same for both scholarship and non-scholarship students.

Regarding academic factors, the popularity of Anadolu University, based on the academic quality and campus among Turkish universities, is shared by both student groups. However, there are also some different points highlighted by scholarship and non-scholarship students separately. A number of scholarship students emphasize the "recognition of degrees and diplomas gained at Anadolu University by European and home countries as an advantage of studying here". In addition, certain students underlined that "Anadolu University has top-ranked programs" that students were studying in their home country or were interested in and the "presence of programs in English".

Significant others are also effective in decisions to study at Anadolu University for both types of students. Friendssuggesting study at Anadolu University are a major factor. These friends are either still studying at Anadolu University or are students of other universities in Turkey. For example, P1 says: "I asked my friends about Anadolu University. They said that it has exchange programs, a good library and a good cafeteria in a really good campus". Additionally, others mention that their "siblings in the Anadolu University" and "teachers in the home country" suggested studying at Anadolu University.

City characteristics are emphasized by both types of students as a critical factor in their decision to study at Anadolu University. Anadolu University is located in Eskişehir, often called 'the student city' by Turkish nationals. Eskişehir was ranked at 1st in 2017 and 2018 at the student-friendly city listing by University Assessments and Research Center (Karadağ \& Yücel, 2018). Besides, people can find lots of artistic and cultural activities in the city and it attracts many domestic tourists.

According to the opinions of the participants, both types of international student share the same ideas as Turkish nationals regarding Eskişehir. In this regard, nonscholarship students especially highlighted "the cost of education and living expenses as being favorable for a student in Eskişehir”. Similarly, its location between Ankara, Istanbul and Izmir connects Eskişehir to these important Turkish cities. However, Eskişehir is not as populated asthese cities. The three major cities mentioned also experience higher crime rates. Unlike these cities, "Eskişehir is a safer and more secure place to study". 


\section{Discussion}

When participants decide to go abroad for higher education, the prestige of a foreign diploma, finding a job easily in their home country, finding better educational opportunities, learning a foreign language, and the instrumentalization of higher education to go abroad are among the pulling factors at work, whereas personal development, personal and professional interests and the role of peer social capital constitute the pushing factors. In addition, significant others play both pushing and pulling roles. Moreover, personal development, and personal and professional interests are also mentioned by some participants from low and middle-income countries from Asia and Africa, which shows that the private rationale (Kondakci, 2011) is also prominent for participants from non-high-income countries. Therefore, these participants also show interest in new cultures, and they act according to their professional interests regarding specialization in a particular field (Hercog, \& Van de Laar, 2013).

All the above factors are also mentioned by previous studies in the literature (Hercog, \& Van de Laar, 2013; Kim, Bankart, Jiang \& Brazil,2018; McCarthy, Sen, \& Fox Garrity, 2012; Ortiz, 2015; Özoğlu, Gür \& Coşkun, 2015; Singh, 2016; Tan, 2015) except the peer social capital and instrumentalization of higher education to go abroad. P3 expresses the presence of an idea of going abroad for higher education in his and his friends' minds at high school. He emphasizes that their school was full of high achieving students wishing to get to better higher education opportunities abroad. As a result, they have certain values or traditions regarding going abroad for higher education, which is also reinforced by the activities of previous students who went abroad. This indicates that they possess social capital in their peer network based on shared norms leading them to go abroad for higher education. On the other hand, P9 mentions that although she had better educational opportunities than in Turkey and attended a better-quality university than Anadolu University, she left her university and country, and came to Turkey, solely because she wanted to go abroad. With assistance from Türkiye Scholarships, she managed to come to Turkey. In this manner, she used higher education as an instrument to go abroad. Thus, the baseline was to go abroad and have different experiences, which would make her feel different from her friends. In this way, she probably thinks that she would gain recognition from others (Jung, 2013).

There are many similarities between the factors leading both scholarship and nonscholarship students to study in Turkey. Specifically, geographic proximity, significant others, integration of western values, similar religious practices, eating habits, a shared history, multicultural environment, Turkish TV shows, Turkey as a secure country, ongoing conflicts or wars in home, bureaucratic bribery and low level of democracy in home country, finding jobs easily after graduating from a Turkish university, low academic and non-academic expenses in Turkey, bilateral agreements between European universities and inadequacies in the higher education system and institutions in home country are all shared by both types of students. Moreover, intolerance of women's education in home country and past experiences in Turkey are only mentioned by non-scholarship students, whereas, the presence of Türkiye Scholarships is expressed only by the scholarship students. All these factors are also compatible with the current literature (Hercog, \& Van de Laar, 2013; Kim et al., 2018; Kondakci, 2011; McCarthy et al., 2012; Ortiz, 2015; Özoğlu et al., 
2015; Singh, 2016; Tan, 2015). Considering all, it can be said that differentiation between the factors drawing scholarship and non-scholarship students are weak because these expressions are too general. For example, intolerance of women's education is mentioned by a non-scholarship woman participant from Afghanistan. However, this could also be emphasized by any other scholarship student from an Asian or African low-income country.

Similarly, most of these factors also play a dual role either pushing or pulling students to study in Turkey. Only geographic proximity, similar religious practices, eating habits, shared history, Türkiye Scholarships, and bilateral agreements with European universities are unique examples of pulling factors. Considering a comparison of countries based on their geographic locations, geographic proximity, similar religious practices, eating habits, shared history, intolerance of women's education, inadequacies in the higher education system and institutions in the home country, better education in Turkey, bureaucratic bribery and low level of democracy in home country are only mentioned by participants from Asian and African countries; whereas past experiences in Turkey is only mentioned by participant from a European high-income country.

In this regard, integration of western values by Turkey, which is also mentioned by most of the students from Europe, Asia and Africa is one of the unique findings of this study. Remembering Kondakci's (2010) arguments on the internationalization capacity of Turkey, integration of western values extends to the cultural bonds of Turkey beyond the Balkans, and to the norms of European high-income countries regarding democracy, human rights and freedom. In this manner, it should be noted that Turkey has cultural bonds with European high-income countries as well as with the countries located in MENA, central Asia and the Balkan region. Therefore, such integration of western values by Turkey could also be critical in attracting students from European or American high-income countries.

Similarly, academic and non-academic expenses are quite low in Turkey. For students from European high-income countries, this factor is very effective in choosing to study in Turkey, even without a scholarship. These students think that educational expenses are low in Turkey because in their countries living expenses are high and universities demand high fees. Actually, students from MENA and central Asian countries also find that educational expenses are favorable in Turkey, because they would pay more if they studied in their countries for lower quality higher education (Greene \& Kirby, 2012; Hercog, \& Van de Laar, 2013; Kim et al., 2018; Kondakci, 2011; McCarthy et al., 2012; Ortiz, 2015; Özoğlu et al., 2015; Singh, 2016; Tan, 2015).

An interesting finding of this study is the effect of Turkish TV shows on CCIS. All of the students who mentioned this come from central Asian countries. In fact, Turkish TV shows have begun to appeal to audiences around the globe. A number of Turkish actors and actresses have received awards for their performances from international organizations. Furthermore, several Turkish film directors have received attention from international film award committees and have won awards. In this regard, the film industry and Turkish TV productions can also be useful for cultural and public diplomacy for prospective international students and their families (Golan, 2013; KathyFitzpatrick, Fullerton \& Kendrick, 2013). 
Furthermore, past good experiences related to Turkey comes to the forefront as a pulling factor only for participants from European high-income countries. In fact, without pilot interviews, this opinion is only mentioned by one participant. As a developing country, Turkey is mostly preferred by students from non-high-income countries of Asia, Africa and eastern Europe. In Turkey, there are only 4,713 (4.36\%) students from the U.S.A., Germany, France, Italy, Spain and U.K in total, including exchange programs in 2017 (HEIMS). Several reasons can be proposed to explain this low figure in Turkey. However, past good experiences related to Turkey may be an effective factor for participants from high-income European countries to study in Turkey. This is because, personal interests and experiencing new cultures are very influential on the decision of going abroad for higher education for students from high-income and developed countries, figuring out the private rationale (Kondakci, 2011).

When it comes to choosing to study at Anadolu University, the popularity of Anadolu University (campus and academic quality), recognition of degrees and diploma gained from Anadolu University in the home country, the presence of programs in English, significant others and city characteristics (low and favorable cost of education and the living expenses) are the major factors affecting CCIS, as is seen in other studies (Hercog, \& Van de Laar, 2013; Kim et al., 2018; McCarthy et al., 2012; Ortiz, 2015; Özoğlu et al., 2015; Singh, 2016; Tan, 2015). All these factors do not differentiate between scholarship and non-scholarship students as well as whether they are from high or low-income countries of Asia, Africa or Europe. However, these factors only play a pulling role to study at Anadolu University.

\section{Conclusion and Recommendations}

According to the findings of the study, it can be said that although there are fewer nonscholarship students than scholarship ones, there is not critical differences between factors affecting scholarship and non-scholarship students' decisions regarding study at Anadolu University at subtheme level.

One possible explanation of this could be that most of the participants are from similar or lower income type countries when compared with Turkey. Only P6 is from a highincome European country. In this regard, there is a homogeneity in the composition of the participants by income type of countries, which could lead students to make similar explanations on college choice process. Besides, having a scholarship could be an essential factor to choose to study in Turkey, but still may not be the dominant factor, figuring out the global student mobility flow from low-income to high-income countries.

However, the non-scholarship student from France (a high-income country), emphasized laicism and individual freedom as similarities between Turkey and France and talked about her past good experiences certain reasons in her decision to study in Turkey. Apart from that four of the five students from central Asian countries (non-high-income countries), stated the effect of Turkish TV shows plays a notable role in their decision to study in Turkey. Hence, although there are lots of similarities in factors affecting CCIS for both scholarship and non-scholarship students, different background characteristics and income types could lead several distinctions in the factors influencing CCIS. 
Furthermore, different factors play different roles either pushing or pulling in the individual (intent to go abroad) and institutional levels (choosing to study at Anadolu University). However, in the national level (choosing to study in Turkey) a very same factor could play both pushing and pulling roles because of the disadvantages of the home countries and the advantages represented in Turkey.

Personal development comes to the forefront as a major factor when students intend to go abroad. In this manner, it should be noted that higher education abroad has numerous functions in the life of students other than its perceived economic, academic and social gains. Similarly, city characteristics and the popularity of Anadolu University (campus and academic quality) are the most important factors affecting students choosing to study at Anadolu University, or at the institutional level.

When personal development of the students and the qualities of the Anadolu University are dealt with together, specifically the university, and broadly the city where the university is located, they should offer students different opportunities enabling the students' academic and social engagement and development (Özturgut, 2013), so that the students should be able to maintain a balance between the lifestyles they developed in their home countries and the new life experiences they would have in the host country, as well as coping with prospective problems. Therefore, although Eskişehir is known as the student city, Anadolu University should put more emphasis on enhancing this city-university relationship and highlight the advantages of living in Eskişehir for international students in its core agenda for public (or student) affairs in the national and international arenas.

When choosing to study in Turkey, integration of western values regarding democracy, human rights and freedom, economic advantages of higher education, cultural and historical bonds and past positive experiences of participants in Turkey are some of the essential factors affecting CCIS. As a geographic and cultural bridge that has existed for centuries, Turkey has fostered unique ties between East and West throughout history. In today's world, when the student mobility rate is higher than ever, Turkey has emerged as a new regional hub for international students although it is located on the periphery, considering that developed countries constitute the center destinations in international student mobility (Kondakci, 2011). This capacity to attract international students, not only from low-income eastern countries but also from high-income western countries can be improved if Turkey is able to promote and sustain its cultural characteristics regarding an appreciation of modernization, democracy, human rights, and freedom. Such an appreciation should also be reflected and promoted more by higher education institutions. Additionally, such efforts would also ensure that international students have positive experiences during their stay in Turkey. However, to increase the experiences of international students with Turkey specifically, summer exchange programs for high school students could be established. Moreover, activities for the promotion of Turkish culture and better marketing of Turkish higher education institutions could also be made from the beginning at the K-12 education level to adults abroad. In this manner, with the co-ordination of the Yunus Emre Institute (YEE), the Turkish Cooperation and Coordination Agency (TIKKA) and the Precedency for Turks Abroad and Related Communities (YTB), these activities, programs, and projects will be operated more effectively, and resources could be allocated more efficiently. 
Finally, for other countries having similar qualities with Turkey, such as being a developing country, there are several insights resulting from this study. Sustaining secure and peaceful environment, favorable education and living expenses in campus and the city, more courses in English, college support for engagement by providing students with academically and socially rich activities could be key factors for attracting international students. Besides, providing international students with scholarships options in the host country could be another effective factor. In this manner, advertisement of the host country and opportunities for international students would be very useful, especially by emphasizing the historical and cultural bonds or similarities between host and home countries.

\section{References}

Altbach, P. G. (2004). Higher education crosses borders: Can the United States remain the top destination for foreign students? Change: The magazine of Higher. Learning, 36(2), $18-25$.

Aslan, C. (2014). Students in foreign countries in the field of educational sciences in Early period of Turkish Republic: 1923-1940 (Unpublished doctoral dissertation).

Bodycott, P. (2009). Choosing a higher education study abroad destination: What mainland Chinese parents and students rate as important. Journal of Research in International education, 8(3), 349-373. 09345818.

Bogdan, C. \& Biklen, K. (1992). Qualitative research for education. An introduction to theory and methods. Allyn and Bacon, Boston.

Braun, V. \& Clarke, V. (2006). Using thematic analysis in psychology. Qualitative Research in Psychology, 3(2), 77-101.

Chen, L. (2007). East-Asian students' choice of Canadian graduate schools. International Journal of Educational Advancement, 7(4), 271-306.

Clarke, V. \& Braun, V. (2014). Thematic analysis. pages 6626-6628, Dordrecht. Springer.

Creswell, J. W. (2003). Research design: Qualitative, quantitative and mixed method approaches. Sage, Oaks.

Creswell, J. W. (2014). Research design: Qualitative, quantitative, and mixed methods approaches. Sage, Oaks.

Fitzpatrick, J. D. K., Fullerton, J., \& Kendrick, A. (2013). Public relations and public diplomacy: Conceptual and practical connections. Public Relations Journal, 7(4), 1-21.

Fraenkel, R. J. \& Wallen, E. N. (2008). How to design and evaluate research in education. McGraw-Hill, New York.

Golan, G. J. (2013). An integrated approach to public diplomacy. American Behavioral Scientist, 57(9), 1251-1255.

Greene, M. \& Kirby, D. (2012). The impact of tuition fees on access and student migration: Lessons from Canada's Atlantic coast. Widening Participation and Lifelong. Learning, 14(1), 72-90.

Hemsley-Brown, J. \& Oplatka, I. (2016). Context and concepts of higher education consumer choice. In Higher education consumer choice. Palgrave, London.

Hossler, D. \& Gallagher, K. S. (1987). Studying student college choice: A three-phase model and the implications for policymakers. College and University, 62(3), 207-221. 
Hossler, D., Schmit, J. L., \& Vesper, N. (1999). Going to college: How social, economic, and educational factors influence the decisions students make. Johns Hopkins University Press, Baltimore.

Jung, J. Y. (2013). Amotivation and indecision in the decision-making processes associated with university entry. Research in Higher Education, 54(1), 115-136.

Karadağ, E. \& Yücel, C. (2018). Öğrenci dostu üniversite şehirleri araştırması. Studentfriendly university cities research: 2018]. Üniar Yayınları.

Kaya, K. (2014). Türkiye’nin Afrika Açılım Stratejisinde Uluslararasi Öğrenci Hareketliliğinin Rolü [Role of International Student Mobility in Turkey's Opening Strategy Towards Africa] (Unpublished Dissertation). Precedency for Turks Abroad and Related Communities.

Kim, D., Bankart, C. A., Jiang, X., \& Brazil, A. M. (2018). Understanding the college choice process of Asian international students. Springer, Cham, Switzerland.

Kirisci, K. (2000). Disaggregating Turkish citizenship and immigration practices. Middle Eastern Studies, 36(3), 1-22.

Kondakci, Y. (2010). Turkey's distinctive position in the internationalization of higher education. Higher education and the Middle East: Serving the knowledge-based. economy, 1(7), 52-54.

Kondakci, Y. (2011). Student mobility reviewed: Attraction and satisfaction of international students in Turkey. Higher Education, 62(5), 573-10.

Kotler, P. \& Fox, K. F. A. (1985). Strategic marketing for educational institutions. PrenticeHall, Englewood Cliffs, NJ.

Lee, E. S. (1966). A theory of migration. Demography, 3(1), 47-57.

Maringe, F. \& Carter, S. (2007). International students' motivations for studying in UK HE: Insights into the choice and decision making of African students. International Journal of Educational Management, 21(6), 459-475.

Mazzarol, T. \& Soutar, G. N. (2002). "Push-pull” factors influencing international student destination choice. International Journal of Educational Management, 16(2), 82-90.

McCarthy, E., Sen, A., \& Garrity, B. F. (2012). Factors that influence Canadian students' choice of higher education institutions in the United States. Business Education \& Accreditation, 4(2), 85-95.

McDonough, P. (1997). Choosing colleges: How social class and schools structure opportunity. State University of, Albany.

McMahon, M. E. (1992). Higher education in a world market. Higher Education, 24(4), 465-482.

McMillan, J. H. \& Schumacher, S. (1993). Research in education: A conceptual introduction. Harper Collins, New York.

Merriam, S. B. (1998). Qualitative research and case study applications in education. Francisco: Jossey-Bass, San.

Merriam, S. B. (2009). Qualitative research: A guide to design and implementation. Francisco: John Wiley \& Sons, San.

Neice, D. B. \& P.H. (1977). Patron for the World, Canadian Bureau for International Education. 
Ortiz, A. (2015). New study: How international bachelor's students choose institutions. World Education Services.

Oğuzlu, T. (2007). Soft power in Turkish foreign policy. australian Journal of international affairs, 61(1), 81-97.

Özturgut, O. (2013). Best practices in recruiting and retaining international students in the US. Current Issues in Education, 16(2), 1-22.

Paulsen, M. B. (1990). College choice: Understanding student enrollment behavior.

Pimpa, N. (2003). The influence of family on Thai students' choices of international education. International Journal of Educational Management, 17(5), 211-219.

Reisman, A. (2007). Jewish refugees from Nazism, Albert Einstein, and the modernization of higher education in Turkey. Aleph, 7.

Saraç, M. A. Y. (2017). Presidential speech in the Turkey-Africa Conference of Ministers of Education.

Singh, J. K. N., Schapper, J., \& Jack, G. (2014). The importance of place for international students' choice of university: A case study at a Malaysian university. Journal of Studies in International Education, 18(5), 463-474.

Singh, M. K. M. (2016). Socio-economic, environmental and personal factors in the choice of country and higher education institution for studying abroad among international students in Malaysia. International Journal of Educational Management, 30(4), 505-519.

Tan, A. (2015). College choice behaviors of international students. SAGE Open, 5(4), 1-14.

Vaismoradi, M., Turunen, H., \& Bondas, T. (2013). Content analysis and thematic analysis: Implications for conducting a qualitative descriptive study. Nursing \& health sciences, 15(3), 398-405.

World, U. . U. (2009). Conference on Higher Education: Final report. The New Dynamics of Higher Education and Research for Societal Change and Development.

\section{Author biography}

Adnan Boyaci is an associate professor in the Department of Educational Sciences, Anadolu University. His major research interests lie in the area of educational management and leadership, higher education administration, internationalization of higher education, and educational policies.

Yakup $\mathrm{Oz}$ is a $\mathrm{PhD}$ candidate in the Educational Administration program at Anadolu University and a research assistant in the Department of Educational Sciences, Karamanoglu Mehmetbey University. His research focused on the school leadership and student achievement, school dropout and social capital, student retention and engagement in higher education and internationalization of higher education. 